\title{
Conference Session: International Volunteering and Development - Learning to be a Global Citizen? ${ }^{1}$
}

\author{
Amy Skinner \\ Research Officer | DEEEP/CONCORD, Belgium \\ Amy.Skinner@concordeurope.org \\ Dr. Eleanor Brown \\ Research Officer | University of York, UK \\ eleanor.brown@york.ac.uk \\ Mark Griffiths \\ Post-doctoral Researcher | University of Oulu, Finland \\ Mark.Griffiths@oulu.fi \\ Kristina Kontzi \\ Facilitator | glokal e.V, Germany | kontzi@glokal.org \\ Maria Koleth \\ PhD Candidate | University of Sydney, Australia \\ mkol9268@uni.sydney.edu.au
}

\section{Context}

The European Association of Development Research and Training Institutes (EADI) organised their 14th General Conference titled "Responsible Development in a Polycentric World: Inequality, Citizenship and the Middle Classes". As part of the event, the EADI Working group Global Learning meets Development organised a session on "International Volunteering and Development: Learning to be a Global Citizen?" The aim of this session was to critically explore the links between volunteering and development from a global citizenship and global learning perspective. Research was presented and discussed amongst both academics and practitioners. This article will provide a brief summary of the presentations followed by a discussion of some of the key points of debate during the session, which we hope will inspire further reflection on volunteer practice and discourse within the wider volunteer community.

\section{Development Education and International Volunteering (Eleanor Brown, University of York)}

Concerned by the ways in which volunteering can challenge or reinforce assumptions about 'development' and 'charity', Eleanor's presentation explored the importance of pre-departure volunteer training. Her research asked the question: When

1 Workshop held on 24 June 2014 as part of the EADI General Conference in Bonn, Germany. 
international volunteering is prepared for through a long-term development education course: are there instances of pedagogies that generate critical thinking and do these challenge ingrained assumptions about development based on charity?

Eleanor's research found that the pre-departure course stressed the importance that volunteering is not about 'helping' but rather an opportunity to share and to learn. Although she found evidence of participative pedagogies and discussion of structural injustice and complexity, this was accompanied by didactic teaching, with a heavy reliance on PowerPoints, often citing controversial facts as the only interpretation, with little space for questioning.

While the course challenged the 'charity' frame and critiqued aid-based attitudes towards development on the one hand, there were occasions where the focus on rural areas and vulnerable groups presented a distorted picture of Latin America. Volunteers tended to relate more to the digestible narratives of benevolence that formed an undercurrent of the development cooperation discourse. There was an implicit acceptance of the premise that development projects are an adequate way to address injustice and participants were often deeply attached to the idea of 'helping' and 'making a difference'. Therefore, Eleanor suggested that perhaps the most important element of such a course is that it provides more time to reflect on the information provided. This means engaging learners in critical open-minded discussions, reflecting on inherent contradictions, exploring alternative responses and overtly challenging stereotypes of poverty. Without this space, international volunteering can reinforce inequalities, regardless of the amount of pre-departure education provided.

\section{Equal Global Citizens? Constructions of Identities in North-South and South-North Volunteer Programmes (Kristina Kontzi, glokal e. V.)}

Drawing on postcolonial theories and discourse analysis, Kristina's presentation focused on the question of constructions of identities within volunteer programmes that aim to form global citizens. It was based on the results of a $\mathrm{PhD}$ thesis submitted in September 2013 on the volunteer service weltwärts (= worldwards) which was set up by the German Federal Ministry for Economic Cooperation and Development (BMZ).

Weltwärts is an example of programmes that mainly send volunteers from the Global North to the Global South. After a long struggle from civil society, the so-called partner organizations and returned volunteers, a South-North component was introduced in November 2013, meaning that volunteers from the Global South come to volunteer in Germany. However, while such programmes portray themselves as contributing to a more just world, Kristina pointed out that their organizational 
structures tend to be heavily biased, with nearly all of the resources - such as financial ones or the power to decide about the programme outlines - residing in the North.

Kristina pointed out that in the previous years of the programme (before the recent introduction of the South-North dimension) volunteers from the North tended to be constructed as 'engaged global citizens'. They seem to be omniscient in terms of the kind of tasks they can carry out and given that they come from a so-called 'developed' country, they seem to be the embodiment of 'development': with their stay abroad they bring modernity to the so-called undeveloped regions and help to develop the Other e. g. through technical knowledge. This reinforces stereotypical, homogenous and racist images of, and structures between, the North and South. The North is portrayed as active, as developed, connected to modernity, knowledge, individuality, sustainability, whereas the South is connected to tradition, to underdevelopment, to poverty and environmental damage and is portrayed as passive.

This then raises the question as to whether, within its new dimension of including volunteers from the South, they are to be considered as the embodiment of 'underdevelopment'? The volunteers' role appears to be to bring the "underdeveloped world" to the places where they are volunteering in Germany, be it kindergarten or other social or environmental projects. Furthermore, the programme stipulates that the volunteers should be strengthening civil society and their partner organisations in their home countries. The South therefore still seems to remain the object of development.

Furthermore, Kristina highlighted that when asked about their impressions of Germany in a video on the official website of the programme, the Southern volunteers paint a picture of a perfect country with no inequality in the school system, a place where "everything happens automatically" and where they will learn a lot to "bring back" home to "help in the development" of their countries. ${ }^{2}$ Again, the object of development and the center of knowledge are clearly one-sided.

Another portrayal of one of the first volunteers in the Süddeutsche Zeitung (02/2014), Lionel Dzidzi from Mozambique, shows the ambivalent setting in which the South-North volunteers are being put into and are putting themselves into. On the one hand they are happy to be able to come to Germany while others are drowning to enter the EU. On the other hand Lionel Dzidzi is quite sceptical about the programme, wondering if his stay abroad is used to legitimise the weltwärts programme and the politics of the Ministry of Development as a whole.

2 see: www.weltwaerts.de 
Kristina pointed out that the stereotypical portrayal of the North and the South still needs to be challenged, and on a structural level Southern NGOs must be part of the programme committee. She emphasised the importance of making it easier for volunteers and their families and friends to obtain visas. She also suggests organizing anti-racism trainings for all of the structures involved and empowerment workshops for volunteers with non-white trainers in Germany, and in the sending countries.

In conclusion, even though South-North volunteer programmes are indeed a tool to break with a colonial logic of those who travel and explore and those who are being travelled to and explored, there are some pitfalls that need to be considered and discussed further. Questions about the power relations especially race, class and gender need to be addressed in order to enable these programmes to challenge power structures rather than reinforce inequalities between the Global South and Global North.

\section{Transcendence and Potential: The feeling and felt Global Citizens of International Volunteering (Mark Griffiths, University of Oulu)}

Mark presented his research based on data collected during time spent with volunteers on International Citizen Service (ICS), a British Government programme that sends 18-25 year olds abroad as "global citizens". There are many of the (by now familiar) processes of neoliberalisation on the programme and the way it positions volunteers as global citizens. Once on the ground, however, there were important feelings and affective moments that passed through the spaces of ICS that Mark felt could not be explained by a neoliberal frame of analysis. These were palpable but not necessarily at the grasp of language. Rather than a traditional presentation of data, Mark therefore adopted an experimental approach and presented his research by recounting a narrative.

The story begins as a meeting of 'Westerners' (volunteers/global citizens) and 'Others' (poor hosts) and emphasises structural differences: this is a meeting 'between disparate peoples'. As the meeting unfolds, however, these structural differences are transcended by the push of bodies meeting on 'non-verbal channels'. Throughout Mark evoked affective moments shared by volunteers and hosts in an attempt to make the narrative performative of such moments in the field: children and volunteers play (and sweat) together in the streets; the sickly sweetness of tea produces connections and the "allure" of the face brings smiling bodies together. Part-rhetorical and part-empirical, the world that unfolds is one populated by "fleshy" bodies whose position in a neoliberal ordering of the world becomes less and less important. 
The presentation therefore makes its argument implicitly, suggesting that the global citizens of international volunteering are feeling and felt. This plays out even despite the neoliberalisation of global citizenship (practice and education) that has been documented in recent research on volunteering. A "Soft" version of global citizenship - these important literatures show - is the most we can expect from western volunteers in the South. This paper told a different story: by drawing on the constitutive embodied moments of the volunteer-host encounter, a world is evoked where the inequalities imposed by neoliberalism are transcended in a way that inspires hope and points to a better future. Global citizenship from this perspective, embodied through emotional and affective experience, is a felt practice, rich in solidarities written on the body that see volunteers emerge as "critical" global citizens with the potential to push against the global inequalities that structure their presence in the South.

\section{Popular Movements: Practices of Responsible Development in Immersion and Volunteering Programmes (Maria Koleth, University of Sydney)}

Maria approached volunteering from a slightly different angle to the other presentations, looking at what is termed 'development tourism'. In the last decade, critical literature has called for development to be reconceptualised as a shared responsibility (van Ufford/Giri 2003). The sharing of this responsibility, through forms of popular engagement with development, has become a complex and, at times, problematic endeavour. As one of the most popular forms of engagement with development, volunteer and immersion tourism reflects the wider shift in responsibility for social welfare from the state to multiple agents within a neoliberal market (Shamir 2008). The key finding of her paper was that, despite the significant criticism directed at irresponsible practices of development tourism, it has given birth to new forms of responsibility that respond to the constraints of a neoliberal economy. These new forms of responsibility were evident in Maria's ethnographic research with returned development tourists in Australia and programmes in Peru and Cambodia through:

- mobile appraisals of the expansion of the development industry. Tourists reported back to networks at home through emails and blogs, spreading information and making assessments of both commercial and traditional development programmes.

- long-term processes of critical questioning of consumerism and global inequality

- immersive and diverse connections to third world communities through continuing fundraising efforts in commercial ventures and NGO campaigns, returning to volunteer again and building friendships with local communities. 


\section{Reflection and Discussion}

The discussion after the presentations focused predominantly on the importance of postcolonial critique and the extrapolation of power within volunteer development programmes. By ignoring colonial relationships, or placing them in the past, a critical analysis of the effect of colonialism on the present situation is not possible. By allowing the charity frame to co-exist with other discourses, there is a danger that participants still understand the problem to some extent as poverty and lack of development. Furthermore, the prevailing power structures underlying relationships between volunteers and host communities inevitably place the Northern volunteer as part of the solution to these problems. Feeling better by being able to offer 'help' to vulnerable 'others' narrows the possibilities for understanding development in terms of alternative paradigms, thereby reducing the possibility of more radical responses (Bryan 2012). It also avoids having to broach uncomfortable questions about who is the real beneficiary of a volunteer placement.

The coming together of researchers from different parts of the world during this session revealed that in some contexts postcolonial perspectives on developmentrelated topics such as volunteering are nothing new and the literatures in this area are quite well developed, while in other countries colonial histories don't seem to appear so prominently on research agendas. The emphasis on postcolonial perspectives revealed the need to apply - and update - such critiques. "It's been done before" is not an excuse to move onto another research frame but a sign that something has remained the same and if gendered and racist knowledge continue to prevail we should not ignore them only because research already exists in this area, but also question why they still prevail.

It is in this exchange that the real (prospective) benefit of the session came out. Taken as an area of research that is indicative of the separation of academics and practitioners, this brings to mind the quite often quoted idea that 'development studies does not tend to listen to subalterns and postcolonial studies does not tend to concern itself with whether the subaltern is eating' (Sylvester 1999: 703). Allowing this to inform our reflection on the session - in which there was a mix between researchers and practitioners and some who are both - it seemed clear that after many years of postcolonial/feminist critique many sending organisations persist with gendered and/or racialised representations of development and poor communities. This, obviously, (re)raises the question of how research and practice speak to each other.

Furthermore, many of the questions in the session reflected significant concern over the commercialisation of development tourism ventures and over their capacity to create critical change in the long-term. Concerns were expressed through an exploration of the disempowering neo-colonial relationships and the privileging of 
globally mobile Northern volunteers in volunteer tourism, as well as complex experiences of race and power in specific locations. In particular, the notion of 'responsibility' towards others within these types of ventures was questioned, especially in relation to programmes that involve children. Indeed, it could be argued that children need a lasting relationship with the people around them and the constant coming-and-going of different volunteers could be unsettling for the children. In this respect, could it in fact be considered irresponsible to organise volunteer tourism with children?

However, there are many different dimensions that need to be considered in a transformative learning experience such as international volunteering. These include not only the intellectual, but also the personal, the affective and the practical. There are very real tensions and from the different approaches discussed in the session it is clear that there are no obvious ways to address these issues. An international volunteering experience can be interpreted in many different ways and we need to think carefully about how we negotiate these. For example, two of the pieces of research explicitly revealed the extent to which volunteering promotes reflection on materialist, consumerist driven development. While some participants focused on the idea that they found that people were 'poor but happy' and there may be a danger that this justifies poverty or legitimises injustice and inequality, the researchers found that rather than justifying poverty on these grounds, volunteers reflected on the unnecessary material consumption in their own lives and its meaninglessness. In this sense it disrupted the notion of development and challenged the idea that progress and standards of living are measured in terms of material wealth.

Moreover, as Mark's research suggested, the lived, affective and emotional experiences of volunteers with their host communities can transcend the neoliberal ordering of the world, and enable volunteers to push against the structures that justify their presence in the South towards inspiring new hope and new pathways for a better future. Indeed, the papers in the session suggested various directions of enquiry, but they all highlighted the importance of paying attention to the nuances of diverse forms of volunteering as opportunities for experiential learning and the fragmented but hopeful possibilities for creating greater knowledge of structures of privilege and disadvantage.

\section{Questions and Future Directions}

Clearly, much remains to be done to reach a deeper understanding of the numerous dimensions of international volunteering. There is the impact on the volunteer, how it affects their knowledge, attitudes and future choices; this might be considered in terms of employability or political and civic engagement, but there are always a range of influences: intellectual, emotional, political etc. Furthermore, there is a need to tackle the "partial geography" of volunteering currently present, which 
focuses on the experiences of the Northern volunteer and the changes to the Northern individual as a result of volunteering, as opposed to the changes within the host communities, their experiences of hosting volunteers and the perspectives of Southern volunteers (Baillie-Smith/Laurie, 2014).

There are further questions around the processes involved in creating meaningful volunteering experiences; how can organisations negotiate the tensions between critical analysis of placements, which may highlight contradictions and reveal uncomfortable neo-colonial power structures on the one hand, and inspiring engagement leading to long-term transformation, on the other? Or perhaps instead of looking at how we can better existing programmes, we should also dare to ask whether it would be better to just put an end to some volunteering programmes?

There are questions around the framework we use in such analysis: Does the model of global citizenship adequately encompass the fragmentary and diverse connections inspired by and enacted within volunteering? Or does the model of global citizenship reproduce Othering processes, whereby the global citizen is connected with modernity and mobility as opposed to the local citizen who is connected to tradition and immobility often forced upon him or her? Do the contingent connections of volunteers constitute a form of citizenship that is critical enough to contest the neoliberal and neo-colonial power structures in which it has evolved and in which it is still embedded? How can issues of racism, sexism and classism be brought into the debate within volunteering programmes?

Finally, there are questions around the practicalities of organising international volunteering programmes. There is much debate about the role of pre-departure training, but the approach and pedagogies used and the criteria against which this is measured all influence how effective, or not, this may be for the volunteers. Similarly, the ways that volunteers engage on their return is an area in which there is much work to do. Research suggests that it is important that there are opportunities for post-placement reflection, but what should this look like? All of these questions are developing in a context of increasing consumerism, in which market demands for commercialised relationships to communities put pressure on governments and organisations. This impacts on the extent to which they can, and do, facilitate the development of critical awareness.

Perhaps what is required is a long-term study of volunteering that seeks to gain better understanding of the effects of this intense emotional and educational experience. It is clear that transformation takes place, but we are yet to really evidence its depths and how transformation in volunteers shapes their interactions with both their host and home communities during and post- placement.

In order to build this understanding, researchers from North and South need to work closely with practitioners, and immerse themselves in the spaces occupied 
by volunteers and sending organisations, to understand the limitations and the insights that come through genuine partnership.

\section{References}

Baillie-Smith, Matt and Nina Laurie (2014): A Geography of International Volunteering and Development, Working paper, http://www.globalvolunteeringresearch.com/ uploads/2/0/1/9/20199153/baillie_smith_and_laurie_working_paper_a_geography_of_international_volunteering_and_development.pdf (accessed on July 16 2014).

Bryan, Audrey (2012): Band-Aid Pedagogy, Celebrity Humanitarianism, and Cosmopolitan Provincialism: A Critical Analysis of Global Citizenship Education, in: Ethical Models and Applications of Globalization: Cultural, Socio-Political and Economic Perspectives, ed. by Charles Wankel and Shaun Malleck, Hershey, PA: Business Science Reference, pp. 262-286.

Shamir, Ronen (2008): The age of responsibilization: on market-embedded morality, Economy and Society 37 (1): 1-19.

Süddeutsche Zeitung (02/2014): Das Ende der Einbahnstraße, Süddeutsche Magazin jetzt. de, http://jetzt.sueddeutsche.de/texte/anzeigen/586107/Das-Ende-der-Einbahnstrasse (accessed on 21 July 2014).

Giri, Ananta Kumar and Philip Qarles Van Ufford (2003): A Moral Critique of Development: Ethics, Aesthetics and Responsibility, Working paper no. 128, DIR \& Institute for History, International and Social Studies, Aalborg University. 